\title{
TIBIAL SPINE AVULSION FRACTURE IN THE ELDERLY
}

\section{Kasetti P.1, Beale D.2., Botchu R. ${ }^{3}$}

ibial spine avulsion fractures are predominantly paediatric fractures that are rarely encountered in adults. These fractures are increasing in incidence and can adversely affect knee stability and mobility if not treated swiftly and appropriately.

Material and methods. We report an unusual case of a tibial spine avulsion in a 68-year-old female and believe this to be the oldest in literature.

Results. This is a highly unusual fracture to be seen in this age demographic. Adults presenting with tibial avulsions often have associated injuries and morbidities.

Conclusion. Optimising prognosis requires an early and accurate diagnosis to guide the appropriate, and often surgical, treatment.

Keywords: tibial avulsion, diagnostics.

Corresponding author: Botchu R., e-mail: drbrajesh@yahoo.com

For citation: Kasetti P., Beale D., Botchu R. Tibial spine avulsion fracture in the elderly. REJR 2020; 10(4):293-296. DOI:10.21569/2222-7415-2020-10-4-293-296.

\section{Received: $\quad$ 05.06.20 $\quad$ Accepted: 22.09 .20 \\ ОТРЫВНОЙ ПЕРЕАОМ МЕЖМЫЩЕАКОВОГО ВОЗВЫШЕНИЯ БОАЬШЕБЕРЦОВОЙ КОСТИ У ПОЖИАОГО ПАЦИЕНТА}

\author{
Касети П.' , Бил А. ${ }^{2}$, Ботчу Р. 3
}

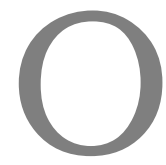

трывные переломы межмыщелкового возвышения большеберцовой кости происходят, в основном, в педиатрической популяции, и редко встречаются у взрослых. Однако, данный тип травмы встречается все чаще и может негативно повлиять на стабильность и подвижность коленного сустава, если не будет проведено своевременное цечение.

Материалы и методы. Представлен клинический случай отрывного перелома межмыщелкового возвышения большеберцовой кости у 68-метней женщины. Ранее в митературе не встречалось описание такой травмы у пожилых пациентов.

Результаты. Представленный случай отрывного перелома межмыщелкового возвышения большеберцовой кости является редким наблюдением в данной возрастной категории. Пациенты с данным типом перелома часто имеют сопутствующие травмы и заболевания.

Выводы. Данный тип травмы требует ранней и точной диагностики для выбора подходящего и, часто, хирургического мечения.

КАючевые слова: отрывной перелом межмыщелкового возвышения, большеберцовая кость, мучевая диагностика.

Контактный автор: Ботчу P., e-mail: drbrajesh@yahoo.com

Для иитирования: Касетти П., Бил Д., Ботчу Р. Отрывной перелом межмышелкового возвышения большебериовой кости у пожилого пациента. REJR 2020; 10(4):293296. DOI:10.21569/2222-7415-2020-10-4-293-296.
1 - Imperial Medical College.

London, UK. 2 - Heath Lodge Clinic. Knowle, UK. 3 - Department of Musculoskeletal Imaging, Royal Orthopaedic Hospital. Birmingham, UK.
1 - Императорский медицинский коммедж. Аондон, Великобритания.

2 - Клиника "Heath Lodge».

Ноул, Великобритания. 3 - Отдемение скеметно-мышечной визуализации Королевской ортопедической больницы. Бирмингем, Великобритания.
Статья получена:
05.06.20
Статья принята:
22.09.20 


\section{A}

tibial spine avulsion, also known as a tibial eminence avulsion, is a fracture of the tibial intercondylar eminence into which the ACL attaches. This is a paediatric-dominated fracture, typically affecting 8 to 14 -year olds $[1,2]$. This injury characteristically involves knee hyperextension combined with valgus rotation during sports-related activities (skiing accidents and cycling falls) [2, 3]. The number of avulsion fractures encountered is increasing due to increased involvement in athletic activities over the past decades [4]. Tibial spine avulsions are rarely encountered in skeletally mature adults and are often secondary to associated injuries or high-energy trauma in road-traffic accidents [5]. Tibial spine fractures manifest in the inability to bear weight and a lax ACL, thus impairing a patient's quality of life [6]. Consequently, prompt diagnosis and treatment, is paramount for good prognoses [5-7].

This case report details an unusual case wherein a 68-year-old female presented with a Meyers and McKeever type IV tibial spine avulsion. There are only 9 reports of tibial spine avulsions at the tibial footprint of ACL in skeletally mature patients, with the oldest report found to be in a 55-year-old female following our literature examination [8,9]. This makes our case report, presenting a 68-year-old female, the oldest patient in literature to suffer from this extremely rare injury.

\section{Case report.}

A 68-year-old female presented with pain and swelling of the left knee following a twisting injury. MR performed demonstrated comminuted minimally displaced fracture of the tibial spine corresponding to the tibial footprint of ACL (Fig. 1). The menisci were normal. There was mild oedema and thickening of the femoral attachment of the deep part of the MCL in keeping with grade 2 sprain of meniscofemoral ligament. The superficial component of the MCL and meniscotibial ligament were intact. There was moderate osseous oedema involving the posterior part of the proximal tibia in keeping with a pivot shift pattern of injury. She was referred to orthopaedic surgeon for surgical reconstruction of the ACL.

\section{Discussion.}

The tibial eminence is a bony confluence between the tibial medial and lateral condyles, which comprises of medial and lateral spines and anterior and posterior recesses [6]. The ACL is a vital intra-articular ligament that runs from the posteromedial aspect of the lateral femoral condyle, traversing anteriorly, and attaching to the medial anterior recess on the tibial intercondylar eminence [2]. The function of the ACL is to limit both the anterior movement and internal rotation of the tibia. Hence, this particular fracture caus- ing tibial displacement results in ACL deficiency, characterised clinically by the pivot-shift phenomenon [10].

A tibial spine avulsion is most commonly found in the paediatric population and represents $2-5 \%$ of paediatric knee injuries with effusion [1]. The most common causes, determined by epidemiological studies, are cycling falls in children and road traffic accidents in adults.

These contrasting aetiologies suggest differing mechanisms of injury, which occurs due to the difference in chondro-epiphyseal maturity. Ossification and fusion of the chrondro-epiphyseal junction at the site of ACL insertion occurs between 14 to 16 years of age, corresponding with the peak of avulsion fracture incidence [11]. Prior to ossification in skeletally immature patients, the ACL insertion site is cartilaginous and hence weak. Thus, avulsion occurs primarily due to the weak ACL attachment site and the ACL itself remains intact [12]. However, following bone ossification, the ACL fibres are comparatively weakened with reduced tensile strength. These fibres are overpowered following high-energy trauma in road traffic accidents, which causes knee hyperextension and is also associated with comminuted tibial eminence fractures [8]. Adult tibial avulsions are also accompanied with damage to other structures such as the menisci, posterior cruciate ligament, medial collateral ligament and bone (i.e. 'kissing' bone contusion) [4, 6, 8]. A worse prognosis is consequently linked with adults due to the related intra-articular fractures and medial collateral ligament injuries [5].

Tibial spine avulsion fractures were first described by Poncet in 1875. Meyers and McKeever later classified the fractures based on bone fragment displacement. This classification is also useful in determining the appropriate treatment [6]. A type I fracture details a non-displaced tibial fracture where the tibial avulsion retains bony apposition. A type II fracture is partially displaced, and the anterior segment of the avulsed fragment is displaced superiorly from the bone bed, producing a beak-like image on lateral radiographs. Type III fractures are completely displaced: Type IIIa simply involves the area of ACL insertion whereas Type IIIb involves the complete intercondylar eminence. Type I and II fractures occur in younger adolescents, whereas type III occur in older adolescents. Finally, a type IV fracture was later added by Casalonga et al. and Zaricznyi, which includes comminution of the displaced tibial spine fragment [6, 11, 13]. A Type IV fracture is what our patient presented with.

Upon clinical examination, tibial spine avulsion often presents as a painful, flexed knee with signs of anterior instability, secondary to a history of trauma or twisting injury. Within hours, knee 


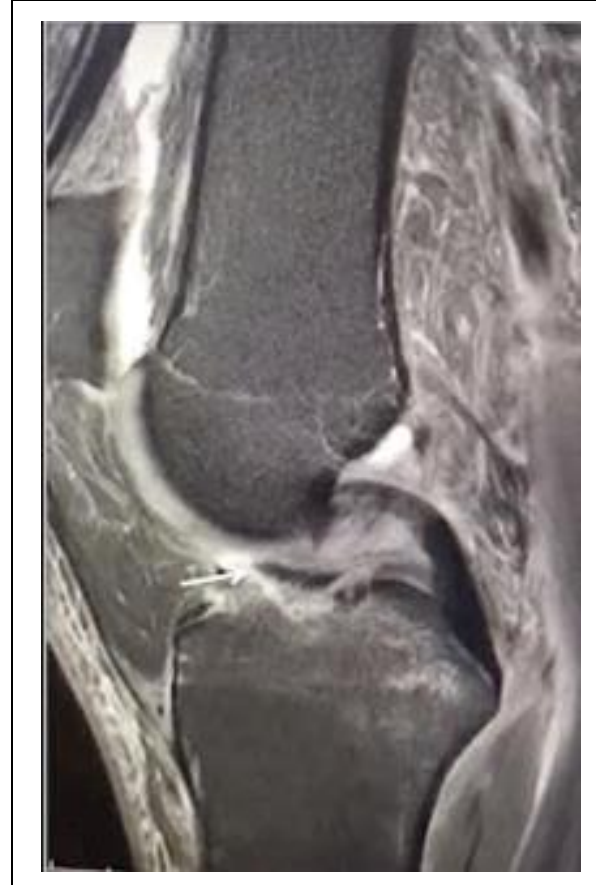

Fig. 1 a (Рис. 1 a)

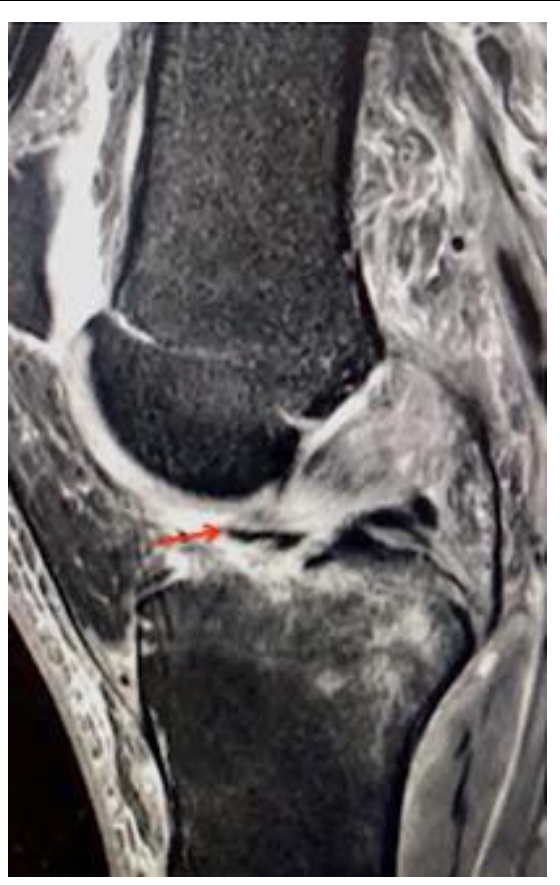

Fig. 1 b (Pис. 1 б)

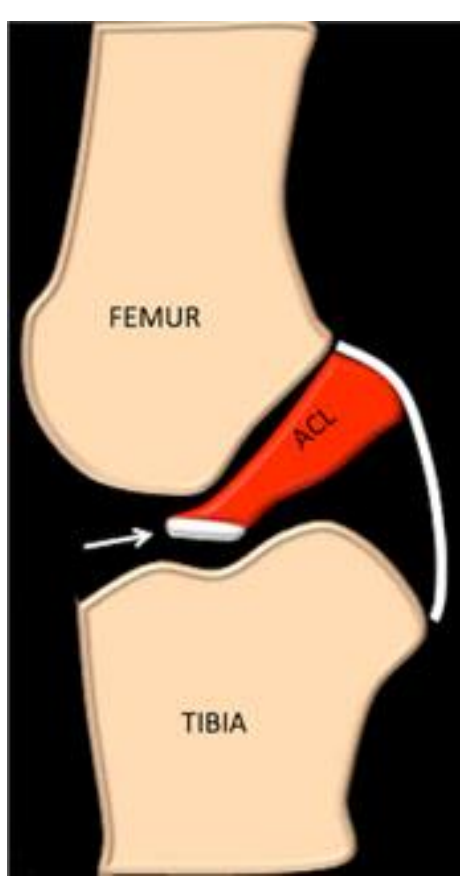

Fig. 1 с (Рис. 1 в)

Fig. 1. MRI (a,b), Sag PDFS, scheme (c).

Avulsion (arrow) of the tibial spine corresponding to the tibial attachment of ACL.

Рис. 1. MPT (a,б), Sag PDFS, схема (в).

Отрывной перелом (стрелка) межмыщелкового возвышения большеберцовой кости, соответствующая месту прикрепления ПКС.

swelling occurs and the injured knee becomes non-weight bearing. Clinical examination may prove challenging in a patient experiencing pain. However, in co-operative patients with tolerable pain, examination may reveal significant knee haemarthrosis and effusion causing limited knee motion. Laxity may also be assessed with a Lachman or pivot-shift test. Plain radiographs are the next step in diagnosis and treatment $[4,6]$.

Radiological findings of avulsion fractures may be difficult to recognise but are necessary to assign a Meyers and McKeever classification, which determines the treatment plan [4].

Tibial spine fractures are assessed with anteroposterior and lateral radiographs to ascertain the fracture type, displacement size and degree [11]. Typically in radiographs, adjacent to the ACL attachment site, small bony fragments are found in the intercondylar eminence with cortical irregularity in the neighbouring tibial eminence [4, 8]. Caution must be taken in paediatric radiographs; the fragment may be missed or underestimated in size as the cartilaginous section of osteochondral fracture fragment is not visible in imaging. If plain radiographs cannot determine fracture displacement, CT should be used due to its inherent higher resolution to assess the nature and comminution of the fracture. CT scans are also useful in pre-operative planning $[1,6,11]$. MR imaging is useful in very small or cartilaginous avulsions and in soft tissue imaging, which can reveal injuries to associated structures such as the menisci, cartilage or ligaments $[6,11]$.

The goals of treatment are threefold: restoring the function and continuity of ACL, removing the fragments and consequent mechanical blocks and re-establishing the tibial plateau conformity [6]. Type I fractures are treated non-surgically and conservatively with immobilisation in a long leg cast for 4 to 6 weeks until radiological fusion is observed [11]. This approach may also be suitable for reducible type II fractures. Typically, surgical treatment is recommended for type II to IV fractures that cannot be reduced. Surgical treatment encompasses fracture fixation and reduction [1, 15]. Over time, surgical treatment has evolved from open reductions and internal fixation to arthroscopic approaches [11].

Today, arthroscopic fracture fixation is the 'gold standard' treatment and is recommended for type II, III and IV fractures [4, 15]. Arthroscopic treatment allows direct visualisation of the injuries with simplified yet accurate diagnosis and reduction; it reduces the complications, hospital stay length and post-operative pain associated with an arthrotomy [15]. In adults, surgical management is often necessary due to the concurrent pathologies and soft tissue entrapment [8]. Ar- 


\section{RUSSIAN ELECTRONIC JOURNAL OF RADIOLOGY}

throscopic fixation can take the form of either screw or suture fixation [7]. Arthroscopic pull through suturing is a minimally invasive technique involving good functional restoration with decreased risk of arthrofibrosis and infection. However, it is technically demanding [1, 7]. The cannulated screw approach is less demanding with shorter mobilisation. However, it is associated with increased physeal damage, second surgery for screw removal and is not appropriate for smaller osteochondral fragments [1, 15]. Under cyclic loading settings, suture fixation may also provide stronger fixation than screw fixation [12]. Hence, suture fixation arthroscopic reduction is

\section{References:}

(1) Macknet D., Yen Y., Joughin E. Tibial Eminence Fracture. Available at:

https://www.orthobullets.com/pediatrics/4022/tibialeminence-fracture [Accessed 15th May 2020].

(2) Anderson C.N., Anderson A.F. Tibial Eminence Fractures. Clinics in Sports Medicine. 2011; 30 (4): 727-742.

(3) Jos S., Anand R., Elenjickal J.P. Clinical outcome of tibial spine ACL avulsion fracture in adults treated with suture bridge fixation. 2018; 4 (2): 99-102.

(4) Gottsegen C.J., Eyer B.A., White E.A., Learch T.J., Forrester $D$. Avulsion fractures of the knee: imaging findings and clinical significance. Radiographics: A Review Publication of the Radiological Society of North America, Inc. 2008; 28 (6): 1755-1770.

(5) NS K., SY H., KM C. Fracture of the tibial spine in adults and children. A review of 31 cases. The Bone \& Joint Journal. 1992; 74B (6): 848-852.

(6) Joshi A., Nagmani S., Basukala B., Kayastha N., Pradhan I. Tibial spine avulsion of ACL. Injuries around the knee. Wolter Kluwer, 2019. PP. 22-44.

(7) Sapre V., Dwidmuthe S.C., Bagaria V., Yadav S. Functional outcome in tibial spine fracture treated with arthroscopic pull through suture technique. Journal of Orthopedics, Traumatology and Rehabilitation. 2015; 8 (1): 6 doi: 10.4103/09757341.183956

(8) Patterson S.P., Christiansen G.B., Daffner R.H. Avulsion fracture of the tibial eminence in an adult with a unique mechanism of injury. Radiology Case Reports. 2018; 13 (4): 843-847 doi: 10.1016/j.radcr.2018.05.015

(9) Atsumi S., Arai Y., Nakagawa S., Inoue H., Ikoma K., Fujiwa- considered superior for displaced or comminuted avulsions, which is typical in the type IV fracture diagnosed in our patient [8].

Conclusion.

A 68-year-old female presented with a type IV tibial avulsion at the tibial footprint of the ACL. This is a highly unusual fracture to be seen in this age demographic. Adults presenting with tibial avulsions often have associated injuries and morbidities. Hence, optimising prognosis requires an early and accurate diagnosis to guide the appropriate, and often surgical, treatment.

ra H., et al. A Case of Nonunion Avulsion Fracture of the Anterior Tibial Eminence. Case Reports in Orthopedics. 2016; 9648473 doi: https://doi.org/10.1155/2016/9648473

(10) Noyes F.R. The Function of the Human Anterior Cruciate Ligament and Analysis of Single- and Double-Bundle Graft Reconstructions. Sports Health. 2009; 1 (1): 66-75.

(11) Sapre V., Bagaria V. Tibial Spine Avulsion Fractures: Current Concepts and Technical Note on Arthroscopic Techniques Used in Management of These Injuries. Regional Arthroscopy. 2013. doi: $10.5772 / 54967$

(12) Inklebarger J., Taylor M.J.D., Griffin M., Clarke T. Fixation failure in an isolated tibial eminence ACL traction avulsion fracture in a paratrooper: is there an association with vitamin $D$ deficiency? Journal of Surgical Case Reports. 2014; (4). doi: 10.1093/jscr/ rju029

(13) Stevens M.A., El-Khoury G.Y., Kathol M.H., Brandser E.A., Chow S. Imaging features of avulsion injuries. Radiographics: $A$ Review Publication of the Radiological Society of North America, Inc. 1999; 19 (3): 655-672.

(14) Strauss E.J., Kaplan D.J., Weinberg M.E., Egol J., Jazrawi L.M. Arthroscopic Management of Tibial Spine Avulsion Fractures: Principles and Techniques. JAAOS - Journal of the American Academy of Orthopaedic Surgeons. 2018; 26 (10): 360-367 doi: 10.5435/JAAOS-D-16-00117

(15) Osti L., Buda M., Soldati F., Del Buono A., Osti R., Maffulli $N$. Arthroscopic treatment of tibial eminence fracture: a systematic review of different fixation methods. British Medical Bulletin. 2016; 118 (1): 73-90. 